\title{
Effect of silicate solubilizing bacteria and fly ash on silicon uptake and yield of rice under lowland ecosystem
}

\author{
S. K. Pedda Ghouse Peera ${ }^{1 *}$, P. Balasubramaniam ${ }^{2}$ and P. P. Mahendran ${ }^{3}$ \\ ${ }^{1}$ Agricultural College, Acharya N.G. Ranga Agricultural University, Bapatla-522 101, Guntur, (A.P.), INDIA \\ ${ }^{2}$ Anbil Dharmalingam Agricultural College and Research Institute, Tiruchirapalli-620 009, (Tamil Nadu), INDIA \\ ${ }^{3}$ Agricultural College and Research Institute, Tamil Nadu Agricultural University, Killikulam-628 252, (Tamil \\ Nadu), INDIA \\ *Corresponding author. E-mail: ghouse.agri@gmail.com
}

Received: March 8, 2015; Revised received: November 2, 2015; Accepted: January 20, 2016

\begin{abstract}
A field experiment was conducted in sandy loam soils of eastern farm, Agricultural Engineering College and Research Institute, Kumulur, Tamil Nadu, India to study the effect of silicon on yield and uptake of rice (var. BPT 5204) during Kharif season of 2010-11 by taking the treatment combinations based on graded levels of Fly Ash (FA), Silicate Solubilizing Bacteria (SSB) and Farm Yard Manure (FYM) at fixed fertilizer schedule. The experimental soil $(0-15 \mathrm{~cm})$ had $\mathrm{pH} 7.22$; organic C $1.4 \%$; available Si $66.0 \mathrm{mg} \mathrm{kg}^{-1}$; available N $266.0 \mathrm{kgha}^{-1}$; available P 14.42 $\mathrm{kgha}^{-1}$ and available $\mathrm{K} 107.50 \mathrm{kgha}^{-1}$. The results of graded levels of FA show that all the growth and yield attributes were significantly influenced by silicon uptake. The mean silicon uptake at panicle initiation, straw and grain at harvest varied from 53.8 - 98.7, 105.5 - 197.2 and 21.4- $62.3 \mathrm{kgha}^{-1}$ respectively, in rice. Number of filled grains per panicle and grain yield displayed conspicuous relationships with content of $\mathrm{Si}$ in grains. The highest mean grain yield of $3622 \mathrm{~kg} \mathrm{ha}^{-1}$ was recorded by the addition of SSB+FYM followed by FYM (3530 kg ha-1), SSB (3310 kg ha-1) and control $\left(3240 \mathrm{~kg} \mathrm{ha}^{-1}\right)$. The combined application of $25 \mathrm{t} \mathrm{ha}^{-1} \mathrm{FA}$ with SSB+FYM was recorded the highest grain yield of $3710 \mathrm{~kg} \mathrm{ha}^{-1}$ which was 16.3 per cent more over yield of control. The results further show that $25 \mathrm{t} \mathrm{ha}{ }^{-1} \mathrm{FA}$ and SSB+FYM have been proved to be superior treatments for best management of silicon in coastal loamy sand soils under irrigated rice ecosystem.
\end{abstract}

Keywords: Farm yard manure, Fly ash, Silicon and rice, Silicate solubilizing bacteria

\section{INTRODUCTION}

Although silicon $(\mathrm{Si})$ is not considered an essential element for higher plants, it has been proven to be beneficial for the healthy growth and development of many plant species, particularly tropical graminaceous plants such as rice (Liang et al., 2007). Total Si removed by rice grown in an Inceptisol varied from 205-611 kg Si ha ${ }^{-1}$ (Narayanaswamy 2009). Although Si fertilization is not a standard practice in India, the beneficial role for the application of $\mathrm{Si}$ in increasing the yield of rice was evident through several studies. Thermal power stations using pulverized coal as fuel and generating large quantities of ash as a by-product. The annual generation of fly ash is projected to exceed 185 million tonne per annum by 2014-15 in India (MOEFCC,2014). This cumbersome volume of fly ash occupies large area of land and possesses threat to environment. Hence, there is an urgent and imperative need to adapt technologies for gainful utilization and safe management of fly ash on sustainable basis. As the fly ash contains high amount of silicon, it was programmed to investigate the effect of fly ash with silicate solubilizing bacteria, farm yard manure on yield and uptake of rice.

\section{MATERIALS AND METHODS}

A field experiment was conducted in a field No. N1, eastern farm of Agricultural Engineering College and Research Institute, Kumulur, Tamil Nadu for rice (in Kharif), replicated thrice in a split plot design. The BPT 5204 for rice was taken as a test crop. The field was divided into four main plots and each main plot into five sub plots carrying the following treatments. The main plot treatments were $\mathrm{M}_{1}$ : Control; $\mathrm{M}_{2}$ : SSB @ $2 \mathrm{~kg} \mathrm{ha}^{-1} ; \mathrm{M}_{3}$ : Farm Yard Manure @ $12.5 \mathrm{t} \mathrm{ha}^{-1}$ and $\mathrm{M}_{4}$ : SSB + FYM and sub plots were graded levels of fly ash@ $0,25,50,75$ and $100 \mathrm{tha}^{-1}$. The initial physico -chemical properties of soil were analysed and characterization of fly ash was carried out for experimentation are mentioned in Table.1. The available $\mathrm{Si}(\mathrm{N} \mathrm{NaOAc}(\mathrm{pH} 4.0)$ extractable $\mathrm{Si}$ ) of experimental soil was low $\left(66.0 \mathrm{mg} \mathrm{Kg}^{-1}\right)$. The fixed NPK recommendation made uniformly to all the plots based on soil test value with Decision Support System for Integrated Fertilizer Recommendation (DSSIFER) module. The major yield limiting attributes viz., number tillers per hill, number of productive tillers per hill and number of filled grains per panicles were recorded. Drymatter production at panicle initiation, straw and 
grain yield were quantified. The samples from panicle initiation, grain and straw at harvest were collected and oven dried at $65^{\circ} \mathrm{c}$ for 72 hours and powdered in Wiley mill. These samples were analysed for content of Si colorimetrically after digestion with tri acid and dissolved with sodium carbonate (Nayar et al., 1975). All the data were subjected to statistical analysis and relevant data for correlation following the standard procedures. Silicon uptake was calculated as following Nutrient uptake $\left(\mathrm{kg} \mathrm{ha}^{-1}\right)=$ Nutrient content $(\%) \times$ Dry matter yield $\left(\mathrm{kg} \mathrm{ha}^{-1}\right) / 100$

\section{RESULTS AND DISCUSSION}

Yield attributes vs. yield: The tiller number per hill varied from 29.6 to 38.3. Among the imposed treatments SSB + FYM registered the highest number of tillers per hill (37.1) followed by FYM (34.8), SSB (33.8) and Control (32.3) (Table 2). The number of tillers per hill was positively correlated with straw yield $(\mathrm{r}=0.47)$ (Table 5). Among different levels, $50 \mathrm{t} \mathrm{ha}^{-1}$ of fly ash resulted higher number of tillers (38.34) followed by $75 \mathrm{t} \mathrm{ha}^{-1}$ (37.5) and $100 \mathrm{t} \mathrm{ha}^{-1}$ (35.3). The number of tillers produced by the addition of fly ash @ $100 \mathrm{t} \mathrm{ha}^{-1}$ with SSB and FYM was statistically at par with application of fly ash @ $50 \mathrm{t} \mathrm{ha}^{-1}$ with FYM which might be due to polymerization of excessively released silicic acid from fly ash on addition of SSB and FYM (Zhang et al., 2008). Fly ash @ $50 \mathrm{t} \mathrm{ha}^{-1}$ with SSB and FYM based treatment recorded the highest tiller number (44.8) where as in terms of number of productive tillers FA@25 t ha ${ }^{-1}$ with SSB and FYM performed

Table 1. Initial characterization of experimental soil and schedule of activities of field experiments.

\begin{tabular}{|c|c|c|}
\hline Particulars & $\begin{array}{l}\text { Fly } \\
\text { Ash }\end{array}$ & $\begin{array}{c}\text { Field No. } \\
\text { N1 }\end{array}$ \\
\hline \multicolumn{3}{|l|}{ Physical properties } \\
\hline Bulk density $\left(\mathrm{Mg} \mathrm{m}^{-3}\right)$ & 1.27 & 1.42 \\
\hline Particle density $\left(\mathrm{Mg} \mathrm{m}^{-3}\right)$ & 1.99 & 2.19 \\
\hline Total porosity $(\%)$ & 42.0 & 35.1 \\
\hline Maximum water holding capacity (\%) & 33.0 & 30.2 \\
\hline Water in air dry fly ash (\%) & 1.32 & NA \\
\hline Mechanical Composition Sand (\%) & 24.15 & 71.38 \\
\hline Silt $\quad(\%)$ & 62.25 & 10.41 \\
\hline Clay $(\%)$ & 6.25 & 16.84 \\
\hline Soil Texture & sil & ls \\
\hline \multicolumn{3}{|l|}{ Physicochemical properties } \\
\hline$\overline{\mathrm{pH}_{1: 2.5}}$ & 9.10 & 7.2 \\
\hline $\mathrm{EC}_{1: 2.5}\left(\mathrm{dSm}^{-1}\right)$ & 0.50 & 0.26 \\
\hline Cation Exchange Capacity $\left(\mathrm{c}\right.$ mole $\left.\left(\mathrm{p}^{+}\right) \mathrm{kg}^{-1}\right)$ & 2.1 & 15.7 \\
\hline Organic Carbon $\left(\mathrm{g} \mathrm{kg}^{-1}\right)$ & 0.11 & 1.4 \\
\hline Available Nitrogen & NA & 266.0 \\
\hline \multicolumn{3}{|l|}{ (Alkaline permanganate $\mathrm{N})\left(\mathrm{kg} \mathrm{ha}^{-1}\right)$} \\
\hline Available Phosphorus (Olsen's P)( $\left.\mathrm{kg} \mathrm{ha}^{-1}\right)$ & NA & 33.0 \\
\hline Available Potassium $\left(\mathrm{NH}_{4} \mathrm{OAc} \mathrm{K}\right)\left(\mathrm{kg} \mathrm{ha}^{-1}\right)$ & $36.5^{*}$ & 107.50 \\
\hline Available Silicon $(\mathrm{NaOAc} \mathrm{pH} 4.0 \mathrm{Si})\left(\mathrm{mg} \mathrm{kg}^{-1}\right)$ & 215. & 66.0 \\
\hline
\end{tabular}

1s- loamy sand; sil-silty loam* in ppm; NA- Not Applicable well. The present findings also supported the results obtained by Das et al., (2013).

The trend of changes in the number of productive tillers per hill was almost similar to that of number of tillers per hill. The productive tillers increased significantly with an increase in levels of fly ash (Table 2). The recorded values did not show any particular trend with progress of crop growth, but mostly the productive tillers increased in all the main plot, sub plot and combinations. Among the different treatments, application of SSB+FYM recorded the highest productive tillers (21.6) followed by FYM alone (20.3), SSB (19.3) and control (18.8). Application of fly ash @ 25 t ha $^{-1}$ with SSB+FYM showed its superiority in terms of productive tiller number (23.6) which might be due to initial deficit in supply of nutrients by slower mineralization of fly ash. The results were corroborated with the investigation of Zhang et al., (2008).

The number of filled grains varied from 130.0 to 157.3 irrespective of treatments and progress of crop growth. SSB+FYM based treatments were comparable and superior to other treatments (157.3) followed by FYM (145.1) and SSB (139.8). Similar results were observed by Nwugo and Huerta (2008) which explained increased photosynthetic rate and translocation of carbohydrates by $\mathrm{Si}$ and adequate $\mathrm{K}$ supply for the development of reproductive organ and filling of storage tissues with photosynthetic products. The number of filled grains positively and significantly correlated with grain yield $(\mathrm{r}=0.85 * *)$ (Table 5).

Yield and Si uptake: An increase in grain yield from applied fly ash ranged from $3294-3710 \mathrm{~kg} \mathrm{ha}^{-1}$ (Table 3 ) depending on the treatment as compared to control, no fly ash application $\left(3104 \mathrm{~kg} \mathrm{ha}^{-1}\right)$. The largest mean grain yield of $3622 \mathrm{~kg} \mathrm{ha}^{-1}$ was recorded by the addition of SSB+FYM followed by FYM (3530 $\left.\mathrm{kgha}^{-1}\right)$, SSB (3310 kg ha $\left.{ }^{-1}\right)$ and control (3240 kg ha-1) (Table $3)$. The treatment received $25 \mathrm{t} \mathrm{ha}^{-1}$ fly ash with SSB+FYM recorded the highest grain yield $(3710 \mathrm{~kg}$ $\mathrm{ha}^{-1}$ ) which might be due to effective utilization of $\mathrm{Si}$ and $\mathrm{K}$ released from the applied fly ash in soil. The increased grain yield was in good agreement with the findings of Chandramani et al., (2009).

The straw yield was varied from 3223 to $4997 \mathrm{~kg} \mathrm{ha}^{-1}$ irrespective of treatments and progress of crop growth. Significant and positive correlation was observed in between applied doses of fly ash and dry matter produced at different growth stages of rice. Among main plot treatments, SSB + FYM registered higher straw yield (4410 kg ha ${ }^{-1}$ ) followed by FYM (4023 kg $\mathrm{ha}^{-1}$ ). Among the levels of fly ash, application of fly ash@25 t ha ${ }^{-1}$ recorded $4337 \mathrm{~kg} \mathrm{ha}^{-1}$ of straw yield which was higher among the different levels of fly ash applied. Application of fly ash @ $25 \mathrm{t} \mathrm{ha}^{-1}$ of fly ash along with SSB+FYM showed its superiority over rest of the treatments $\left(4997 \mathrm{~kg} \mathrm{ha}^{-1}\right)$ (Table 3). The increase in yield of 8.35 per cent was reported by the application of fly ash alone. Increase in yield of 12.4 

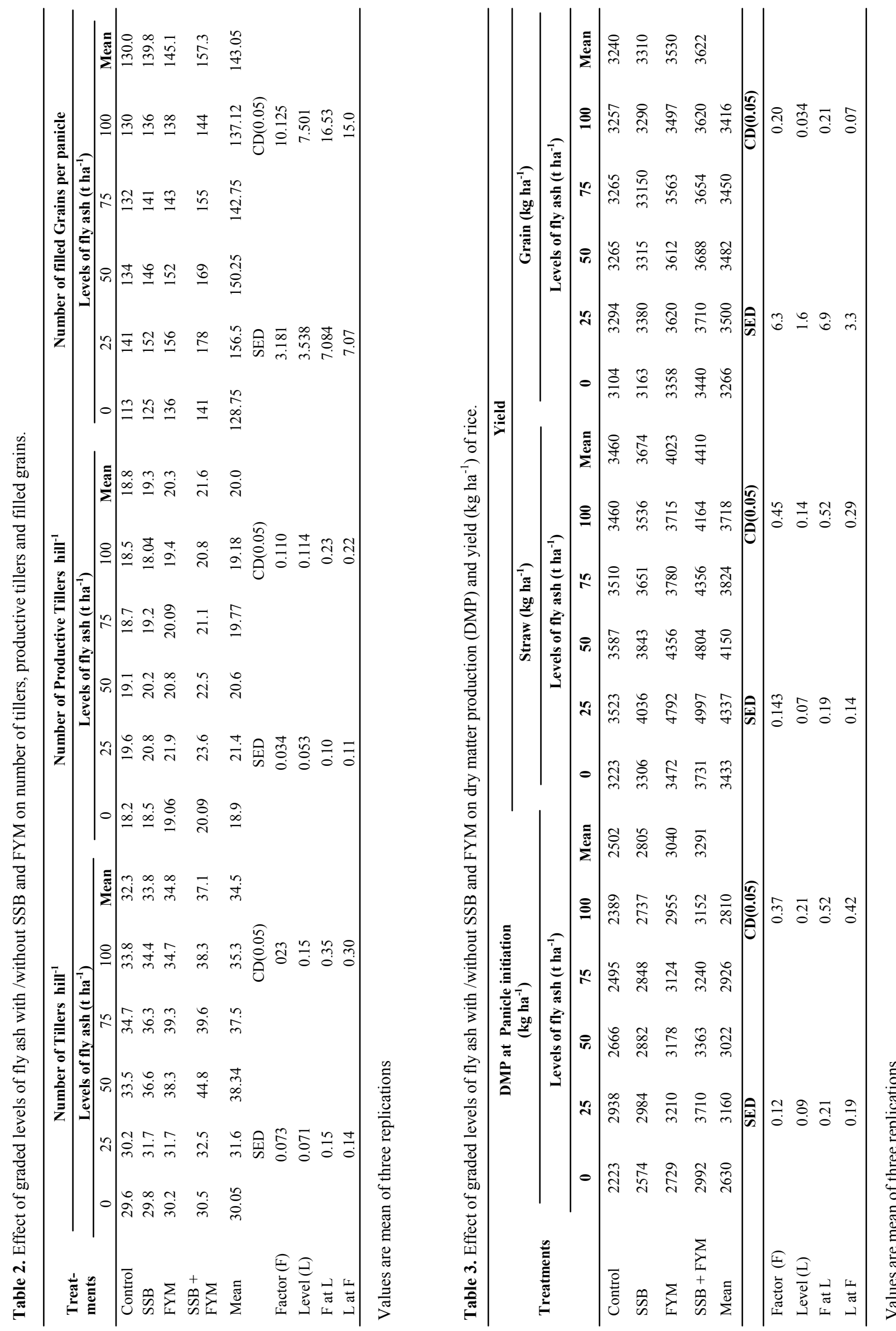
and 22.1 per cent registered which might be due to low $\mathrm{Si}$ status and effective utilization of Si released from the applied fly ash in soil. Similar results were observed in findings of Das et al., (2013). Among levels of fly ash, application of $25 \mathrm{t} \mathrm{ha}^{-1}$ of fly ash recorded maximum straw yield as explained in earlier findings of Karmakar et al.,(2010).

The results suggested that the highest $\mathrm{Si}$ uptake was observed in straw $\left(149.5 \mathrm{~kg} \mathrm{ha}^{-1}\right)$ followed by plant at panicle initiation $\left(76.28 \mathrm{~kg} \mathrm{ha}^{-1}\right)$ and grain $(39.42 \mathrm{~kg}$ $\left.\mathrm{ha}^{-1}\right)$. In grain, the uptake of Si ranged from 21.4 to $62.3 \mathrm{~kg} \mathrm{ha}^{-1}$. Among the different main treatments, SSB + FYM recorded the highest mean uptake of 49.4 $\mathrm{kg} \mathrm{ha}^{-1}$ followed by FYM (42.8 $\mathrm{Kg} \mathrm{ha}^{-1}$ ), SSB (34.6 kg $\left.\mathrm{ha}^{-1}\right)$. Application of fly ash @ $100 \mathrm{t} \mathrm{ha}^{-1}$ with SSB + FYM registered the highest grain uptake of $62.3 \mathrm{Kg} \mathrm{ha}^{-1}$. However, it was statistically at par with application of fly ash@25 tha ${ }^{-1}$ along with SSB + FYM. The trend of changes in straw Si uptake was similar to grain. Among the different main treatments the highest mean Si uptake of $178.6 \mathrm{~kg} \mathrm{ha}^{-1}$ was registered by the addition of SSB + FYM followed by FYM $(157.5 \mathrm{~kg}$ $\left.\mathrm{ha}^{-1}\right)$, SSB (140.3 $\left.\mathrm{kg} \mathrm{ha}^{-1}\right)$ and control (121.6 $\left.\mathrm{kg} \mathrm{ha}^{-1}\right)$ (Table 5). Among the graded levels of fly ash, the highest mean uptake of $164.6 \mathrm{~kg} \mathrm{ha}^{-1}$ was recorded by the addition of $25 \mathrm{t} \mathrm{ha}^{-1}$ of fly ash. Though the application of $50 \mathrm{t} \mathrm{ha}^{-1}$ recorded the highest straw uptake which was statistically at par with $25 \mathrm{t} \mathrm{ha}^{-1}$ with SSB and FYM (197.2 $\left.\mathrm{kg} \mathrm{ha}^{-1}\right)$. It is suggested that rice straw should contain $34 \mathrm{~g} \mathrm{~kg}^{-1}$ of $\mathrm{Si}$ for optimum yield production (Richard et al., 2013). Simple correlation matrix (Table 5) indicated that silicon uptake has been found to be significantly correlated with grain yield and yield attributes of rice. It is vivid that the uptake was due to increased dry matter production and content of Si. It was accelerated with advancement of growth stages. The uptake of Si in straw was greater than grain in contrast to the rest of the nutrients.

\section{Conclusion}

It was concluded that in sandy loam soil, the growth and yield attributes viz., plant height, number of tillers and numbers of filled grains were increased by the addition of $25 \mathrm{t} \mathrm{ha}^{-1}$ fly ash with SSB+FYM. The highest yield of grain and straw was recorded by the addition of $25 \mathrm{t} \mathrm{ha}^{-1}$ fly ash with SSB+FYM. The increase in graded levels of fly ash significantly increased $\mathrm{Si}$ content in straw and grain. The maximum Si content was observed by application of fly ash @ $100 \mathrm{t} \mathrm{ha}^{-1}$ with SSB + FYM. The uptake of Si was accelerated with advancement of growth stages. The application of fly ash @ $25 \mathrm{t} \mathrm{ha}^{-1}$ with SSB + FYM registered maximum uptake of $\mathrm{Si}$. Similar to the content of $\mathrm{Si}$ in straw, the uptake of $\mathrm{Si}$ in straw was also greater than grain. From the experiment application of $25 \mathrm{t} \mathrm{ha}^{-1}$ fly ash with SSB+FYM proved to be superior treatment in improving yield attributes and yield in rice. It can be taken up as the best alternative 
Table 5. Simple correlation matrix showing the relationship of silicon uptake at different growth stages of rice with grain yield

\begin{tabular}{|c|c|c|c|c|c|c|}
\hline Parameter & $\begin{array}{c}\text { No. of } \\
\text { productive } \\
\text { tillers }\end{array}$ & $\begin{array}{c}\text { Number } \\
\text { of filled grains }\end{array}$ & $\begin{array}{c}\text { Si } \\
\text { at PIS }\end{array}$ & $\begin{array}{c}\text { Si at straw } \\
\text { HS }\end{array}$ & $\begin{array}{c}\text { Si at } \\
\text { grain } \\
\text { HS }\end{array}$ & $\begin{array}{c}\text { Grain } \\
\text { yield }\end{array}$ \\
\hline No. of productive tillers & 1 & & & & & \\
\hline Number of filled grains & $0.92 * *$ & 1 & & & & \\
\hline Si uptake at PI & $0.69^{*}$ & $0.74 * *$ & 1 & & & \\
\hline Si at straw & $0.79^{*}$ & $0.84 * *$ & $0.94 * *$ & 1 & & \\
\hline $\mathrm{Si}$ at grain & $0.69^{*}$ & $0.72 *$ & $0.96 * *$ & $0.89^{* *}$ & 1 & \\
\hline Grain yield & $0.87 * *$ & $0.85 * *$ & $0.89 *$ & $0.90^{* *}$ & $0.87 * *$ & 1 \\
\hline
\end{tabular}

* Significant at the 0.05 probability level and ** significant at the 0.01 probability level.

for the effective replenishment of silicon in intensively rice growing soils.

\section{ACKNOWLEDGEMENTS}

The investigation was funded by Fly Ash Unit of Department of Science and Technology, Govt. of India. The authors pay gratitude to Chairman and members of Programme Advisory Committee and Project Monitoring Committee for their critical comments during the period of investigation.

\section{REFERENCES}

Chandramani, P., Rajendran, R., Sivasubramanian, P. and Muthiah, C. (2009). Management of hoppers in rice through host nutrition. A novel approach Journal of Biopesticides. 2(1): 99-106.

Das, B.K., Choudhury, B.H. and Das, K.N. (2013). Effect of integration of fly ash with fertilizers and FYM on nutrient availability, yield and nutrient uptake of rice in inceptisols of Assam, India. International Journal of Advancements in Research and Technology. 2(11):190-208.

Karmakar, S., Mittra, B.N. and Ghosh, B.C. (2010). Enriched coal ash utilization for augmenting production of rice under acid lateritic soil. Coal combustion and gasification products. 2: 45-50.
Liang Y, Sun W, Zhu Y.G. and Christie, P. (2007). Mechanisms of silicon-mediated alleviation of abiotic stresses in higher plants: a review. Environmental Pollution.147: 422-428.

MOEFCC Annual report (2014). Ministry of Environment, Forests and Climate Change, Government of India, New Delhi.

Narayanaswamy, C. and Prakash, N.B. (2009).Calibration and categorization of plant available silicon in rice soils of South India. Journal of plant nutrition. 32 (8): 1237 1254.

Nayar, P.K., Misra, A.K. and Patnaik, S.(1975). Rapid micro determination of silicon in rice plant. Pl. Soil. 42(2): 491-494.

Nwugo Ch C, Huerta A. J. (2008). Effects of silicon nutrition on cadmium uptake, growth and photosynthesis of rice exposed to low-level cadmium. Plant and Soil. 311: 73-86.

Richard J. Haynes, Belyaeva, O.N. and Kingston, G. (2013).Evaluation of industrial wastes as sources of fertilizer silicon using chemical extractions and plant uptake. Journal of Plant Nutrition and Soil Science. 176 (2): $238-248$.

Zhang Ch, Wang L, Nie Q, Zhang W and Zhang, F. (2008). Long-term effects of exogenous silicon on cadmium translocation and toxicity in rice (Oryza sativa L.). Environmental and Experimental Botany, 62: 300-307. 